UDK 630*232.41:582.632.2

Original scientific paper

\title{
ANALYSIS OF MORPHOLOGICAL QUALITY PARAMETERS OF ONE- YEAR OLD BARE ROOT SESSILE OAK (Quercus petraea (Matt.) Liebl) SEEDLINGS
}

\author{
Vladan POPOVIĆ ${ }^{1}$, Aleksandar LUČIĆ ${ }^{l}$, Ljubinko RAKONJAC ${ }^{l}$, \\ Ivona KERKEZ JANKOVIĆ
}

\begin{abstract}
The paper analyzes the morphological quality parameters of one-year-old sessile oak (Quercus petraea (Matt.) Liebl) seedlings and their interrelations. Based on the performed analyzes, it was determined which of the measured morphological parameters, with minimal time and resources spent, gives the most accurate estimate of the quality of one-year old seedlings.

For the conducted research, seedlings were produced in the nursery of the Institute of Forestry in Belgrade, in uniform environmental conditions from seed collected in seed stand RS-2-2-qpe-22-169. The seedlings were produced in the same nursery seedbed, and the sample for analysis was taken by dividing the seedbed into four sections and taking 30 seedlings from each section by random sampling. The following morphological parameters were measured: root collar diameter, height of seedlings, weight of above and underground part of seedling in absolutely dry condition and root volume. Based on the measured values, height ratios were calculated as follows: height:root collar diameter, weight of aboveground part of seedling: weight of underground part of seedling, and quality index.

The height of the seedlings and root collar diameter are good indicators of quality, which is confirmed by the positive correlative relationships with other measured morphological parameters. A stronger dependence has been found in the root collar diameter, especially with the quality index, so it can be recommended as a good indicator of the quality of the one-year old sessile oak seedlings. The quality index has been confirmed as the most comprehensive morphological indicator of the seedling quality.
\end{abstract}

Key words: sessile oak, seedlings, quality, morphological parameters.

\footnotetext{
${ }^{1}$ Institute of Forestry, Belgrade, Serbia

${ }^{2}$ University of Belgrade - Faculty of Forestry, Belgrade, Serbia
} 


\title{
АНАЛИЗА МОРФОЛОШКИХ ПАРАМЕТАРА КВАЛИТЕТА ЈЕДНОГОДИШЫИХ САДНИЦА КИТЬАКА (Quercus petraea (Matt.) Liebl) СА ГОЛИМ КОРЕНОМ
}

\begin{abstract}
Извод: $У$ раду су анализирани морфолошки параметри квалитета једногодишњих садница храста китњака (Quеrсиs petraea (Matt.) Liebl) и ґихови међусобни односи. На основу обављених анализа утврђено је који од мерених морфолошких параметара, уз минимално трошење времена и средстава даје најтачнију процену квалитета једногодишњих садница.

За спроведена истраживања саднице су произведене у расаднику Института за шумарство у Београду, у уједначеним условима средине од семена сакупьеног у семенској састојини RS-2-2-qре-22-169. Саднице су произведене у истој леји, а узорак за анализе је узет тако што је леја подељена на четири дела и из сваког дела је методом случајног узорка узето по 30 садница. Мерени су следећи морфолошки параметри: пречник у кореновом врату, висина садница, маса надземног и подземног дела садница у апсолутно сувом стағу и запремина корена. На основу измерених вредности израчунати су односи висина:пречник у кореновом врату, маса надземног:маса подземног дела саднице и индекс квалитета.

Висина садница и пречник у кореновом врату су добри показатељи квалитета, што је потврђено позитивним корелативним везама са осталим мереним морфолошким параметрима. Јача зависност је утврђена код пречника у кореновом врату, нарочито са индексом квалитета, па се он може препоручити као добар показатељ квалитета једногодишьих садница китьака. Индекс квалитета се потврдио као најобухватнији морфолошки показатељ квалитета садница.
\end{abstract}

Кључне речи: китњак, саднице, квалитет, морфолошки параметри.

\section{INTRODUCTION}

The seedling quality in general has been object of researches for many years, and a finding of the most efficient and at the same time most cost-effective method is an essential element in the nursery production. The seedling quality is one of the main indicators of the afforestation success, since it can predict the field performance of the seedlings and their ability to survive under the different mechanical and environmental stress (Wilson and Jacobs, 2006). The primary objective of the seedling quality assessment is to quantify the levels of the morphological and physiological traits that result in an accurate assessment of the seedling status in terms of assessing the potential for future growth (Wilson and Jacobs, 2006).

According to the Serbian Law on Forest Reproductive Material ("Official Gazette of RS", no. 135/2004, 8/2005), seedlings of hardwood species produced must meet the quality criteria according to the current standard SRPS D.Z2.112:1968. The quality assessment is mostly based on the morphological parameters (Mohammed 1997; Saha et al., 2012) and rarely on the physiological ones (Wilson and Jacobs, 2006). The most frequently used characteristics are the height of the seedlings and the root collar diameter (Ivetić et al., 2017), primarily because of ease and efficiently measurement. The root collar diameter can be 
considered as the best single parameter for predicting the success of the seedling performance in the field, as it is always positively correlated with survival, while the seedling height can have either positive or negative effect (Ivetić, 2013; Ivetić et al., 2017). Other seedling quality parameters such as mass and volume of the root are less commonly used because they are more destructive to seedlings and more complicated to perform. Ratios height:root collar diameter (HD), weight of aboveground part of seedling: weight of underground part of seedling (SR), and quality index (QI) are not used in the assessment of the seedling quality in the nursery production in Serbia (Ivetić et al., 2017).

The sessile oak forests cover $4.9 \%$ of the all forests of Serbia according to their species affiliation (Banković et al., 2008; Ratknic and Rakonjac, 2010). Sessile oak is one of the two most common species of oak in the nursery production of Serbia. Most common types of sessile oak (Quercus petraea (Matt.) Liebl) seedlings are bare root, $1+0,2+0,3+0$ (Ivetić et al., 2017).

This study aims to determine which of the morphological parameters of the one-year-old sessile oak seedlings are most indicative to measure the most accurate quality assessment with minimal time and expense.

\section{MATERIALS AND METHODS}

For the conducted research seedlings were produced in the nursery of the Institute of Forestry in Belgrade, in uniform environmental conditions from seed collected in the seed stand RS-2-2-qpe-22-169. The seed sowing was carried out in April 2017 in a nursery seedbed $(1 \times 10 \mathrm{~m})$. The row spacing was $15 \mathrm{~cm}$, the rows were parallel to the longer side of the row. At the end of the growing season, in October, the seedbed was divided into four parts; per 30 seedlings were taken from each part by random sampling for analysis. The seedlings were carefully removed to minimize the root damage. The following morphological parameters were measured: root collar diameter, height of seedlings, weight of above and underground part of seedling in dry condition and root volume. Based on the measured values, the following ratios were calculated - height:root collar diameter (sturdiness quotient), weight of aboveground part of seedling: weight of underground part of seedling, and quality index.

The height of the seedlings was measured by a ruler with an accuracy of 0.1 $\mathrm{cm}$ and the root collar diameter by a digital nonius with an accuracy of $0.01 \mathrm{~mm}$. For weight measurement purposes, the above-ground part was separated from the roots and separately dried in a Binder type oven at $105^{\circ} \mathrm{C}$ for 48 hours. The weight of the aboveground part and the weight of the root were measured on an electronic balance with an accuracy of $0,01 \mathrm{~g}$. The core coefficient was calculated by Roller 1977 and the quality index by Dickson et al. 1960. The root volume was measured by the water extrusion method (Burdett, 1979).

The measured data were statistically processed in the Statistica 7 software package (StatSoft, Inc. 2004). For the measured morphological parameters, mean, standard deviation, minimum and maximum values were calculated. The interdependence of the measured parameters was determined by calculating a linear correlation coefficient, and the influence of the position of seedlings in the seedbed on 
morphological parameters was examined using one-way analysis of variance (OneWay ANOVA).

\section{RESULTS AND DISCUSSION}

The mean value of the root collar diameter of the measured seedlings is 3.52 $\mathrm{mm}$, with ranging from 2.09 to $5.48 \mathrm{~mm}$. The average height of the seedlings is $14.8 \mathrm{~cm}$, and the measured values range from 6.5 to $24 \mathrm{~cm}$. The weight of the above-ground part of the seedlings ranges from 0.29 to $3.52 \mathrm{~g}$ with a mean value of $1.62 \mathrm{~g}$. The root weight ranged from 0.52 to $7.59 \mathrm{~g}$ with a mean of $3.18 \mathrm{~g}$. Higher weight of the aboveground part indicates the higher capacity of photosynthesis and growth potential, while the root system weight represents the potential for higher growth and survival percentage (Ivetić, 2013), but the weight measurement is destructive for the seedlings, which limits the wider application of this parameter.

The root volume ranges from 1 to $13 \mathrm{~cm} 3$, with the mean value of $4.8 \mathrm{~cm} 3$. The mean HD ratio is 4.24 and can be considered satisfactory for the one-year-old sessile oak seedlings. The ratio between the weight of the above-ground part and the root weight in the dry condition ranges from 0.11 to 2.25 . The mean of this ratio is $0.72(2: 3)$. The seedling quality index has high variability and ranges from 0.21 to 2.86 , with a mean of 1.25 (Table 1 ).

Table 1. Descriptive statistics parameters of mean values for measured morphological parameters of one-year old sessile oak seedlings

\begin{tabular}{|l|l|l|l|l|}
\hline & Mean & Minimum & Maximum & Std.Dev. \\
\hline $\mathrm{D}(\mathrm{mm})$ & 3.52 & 2.09 & 5.48 & 0.74 \\
\hline $\mathrm{H}(\mathrm{cm})$ & 14.8 & 6.5 & 24 & 4.35 \\
\hline $\mathrm{SM}(\mathrm{g})$ & 1.62 & 0.29 & 3.52 & 1.21 \\
\hline $\mathrm{RM}(\mathrm{g})$ & 3.18 & 0.52 & 7.59 & 3.61 \\
\hline $\mathrm{RV}\left(\mathrm{cm}^{3}\right)$ & 4.8 & 1 & 13 & 4.9 \\
\hline $\mathrm{HD}$ & 4.24 & 1.24 & 6.37 & 0.98 \\
\hline SD & 0.72 & 0.11 & 2.25 & 0.52 \\
\hline QI & 1.25 & 0.21 & 2.86 & 0.61 \\
\hline
\end{tabular}

Legend: D - Diameter, H - Average height, SM - Weight of the aboveground part, RM - Root weight, RV - Root volume, HD - Height: diameter ratio, SD - Weight ratio of the aboveground and underground parts, QI - Quality index.

Table 2. Correlation coefficients between the examined quality indicators of oneyear old sessile oak seedlings

\begin{tabular}{|l|l|l|l|l|l|l|l|l|}
\hline & D & H & SM & RM & RV & HD & SR & QI \\
\hline D & 1.00 & 0.52 & 0.44 & 0.51 & 0.56 & -0.48 & -0.21 & $\mathbf{0 . 7 4}$ \\
\hline H & & 1.00 & 0.39 & 0.57 & 0.48 & 0.22 & -0.19 & $\mathbf{0 . 7 1}$ \\
\hline SM & & & 1.00 & 0.65 & 0.71 & 0.09 & 0.11 & 0.62 \\
\hline RM & & & & 1.00 & 0.83 & -0.19 & -0.41 & 0.59 \\
\hline RV & & & & & 1.00 & -0.11 & -0.32 & 0.56 \\
\hline HD & & & & & & 1.00 & 0.12 & -0.35 \\
\hline SR & & & & & & & 1.00 & 0.26 \\
\hline QI & & & & & & & & 1.00 \\
\hline
\end{tabular}

Table 2 shows the correlation coefficients between the examined quality indicators of the one-year old sessile oak seedlings. The strongest correlation was found between the root collar diameter and the quality index (0.74). The height of 
the seedlings is also strongly correlated with the quality index (0.71). The correlation coefficient between the root collar diameter and the height of the seedlings is 0.52 . The quality index is in a strong, positive correlation with all measured parameters, except for the sturdiness quotient.

The mass of the above-ground part of the seedlings is in a positive, significant correlation with all observed parameters except the HD and SR ratios. The strongest correlation it has with the quality index $(0.80)$ and the weakest with the diameter in the root neck (0.38) (Table 2).

In order to determine the influence of the position of seedlings in the nursery seedbed on the investigated morphological parameters, a one-way analysis of variance (One-Way ANOVA) was performed. The obtained results indicate the absence of the position influence on the observed parameters of the seedlings (Table 3).

Table 3. Analysis of variance - influence of the position of seedlings in the nursery seedbed on the quality indicators of one-year old sessile oak seedlings

\begin{tabular}{|l|l|l|l|l|}
\hline & SS & MS & F & p \\
\hline D & 1.653 & 0.7124 & 0.5121 & 0.6231 \\
\hline H & 13.21 & 5.251 & 0.2314 & 0.8322 \\
\hline SM & 0.203 & 0.1154 & 0.1121 & 0.9129 \\
\hline RM & 42.113 & 25.6214 & 1.1124 & 0.1257 \\
\hline RV & 31.721 & 13.335 & 0.8116 & 0.4935 \\
\hline HD & 2.703 & 1.116 & 0.5158 & 0.6423 \\
\hline SR & 1.715 & 0.813 & 1.906 & 0.1501 \\
\hline QI & 0.438 & 0.211 & 0.517 & 0.5820 \\
\hline
\end{tabular}

The measured one-year old sessile oak seedlings according to the measurement data obtained are within the range of values prescribed by the standard for hardwood seedlings. Although the most commonly used quality indicators are seedling height and root collar diameter, the quality index has proven to be the most comprehensive morphological indicator of the seedling quality. The quality index in previous studies has been positively correlated with the growth and survival of seedlings in the field (Tsakaldimi et al. 2012; Ivetić et al. 2016; Popović et al. 2015; Popović et al. 2017). The quality index is very extensive and combines seedling biomass with the height and root collar diameter (Dickson et al., 1960), which may be an obstacle to the wider application of this parameter. HD ratio combined with individual values of height and root collar diameter contributes to the accuracy of predicting the success of seedling survival and growth in the field (Ivetić et al., 2016). The low HD ratio indicates a greater potential for seedlings to survive after exposure to transplant stress (Ivetić et al. 2016), although there are some conflicting results (Tsakaldimi et al. 2012; Devetaković et al. 2017). 


\section{CONCLUSION}

Based on all the data analyzed, the height of the seedlings and the root collar diameter justify their wide application in the evaluation of the seedling quality. This is supported by the strong positive correlation of these two parameters with the quality index, which is the most comprehensive morphological indicator of the seedlings quality.

The obtained results need to be verified in future researches, both on the sessile oak and on other hardwood species, after which these results will be more significant. The first confirmation and verification of the results should be done after transplanting the seedlings in the field and investigating the success of their growth and survival.

Acknowledgements: This paper was realized within the projects: "Development of technological procedures in forestry with the aim of realizing optimal forestation" (TR 31070) and "Forest plantations in order to increase forestation Serbia" (TR31041), funded by the Ministry of Education, Science and Technological Development of the Republic of Serbia.

\section{REFERENCES}

Banković, S., Medarević, M., Pantić, D., Petrović, N. (2009): National Forest Inventory of the Republic of Serbia-Forest Fund of the Republic of Serbia. Belgrade: Ministry of Agriculture of Forestry and Water Management of the Republic of Serbia - Forest Administration (In original: Banković, S., Medarević, M., Pantić, D., Petrović, N. (2009): Nacionalna inventura šuma Republike Srbije-Šumski fond Republike Srbije. Beograd: Ministarstvo poljoprivrede šumarstva i vodoprivrede Republike Srbje-Uprava za šume).

Burdett, A. N. (1979): A nondestructive method for measuring the volume of intact plant parts. Can. J. For. Res. 9 (120-122).

Devetaković, J., Maksimović, Z., Ivanović, B., Baković, Z., Ivetić, V. (2017): Stocktype effect on field performance of Austrian pine seedlings. Reforesta 4: 21-26. https://dx.doi.org/10.21750/REFOR.4.03.42

Dickson, A., Leaf, A. L., Hosner, J. F. (1960): Seedling quality - soil fertility relationships of white spruce and red and white pine in nurseries. Forest Chron. 36: 237-241

Ivetić, V. (2013): Handbook on Seed production, seedling production and afforestation (In original: Praktikum iz Semenarstva, rasadničarstva i pošumljavanja). University of Belgrade - Faculty of Forestry, Belgrade, Serbia. 213 p.

Ivetić, V., Grossnickle, S., Škorić, M. (2016): Forecasting the field performance of Austrian pine seedlings using morphological attributes. iForest 10: 99-107. https://doi.org/10.3832/ifor1722-009

Ivetić, V., Maksimović, Z., Kerkez, I., Devetaković, J. R. (2017): Seedling Quality in Serbia-Results from a Three-Year Survey. Reforesta 4: 27-53. 
Mohammed, G. H. (1997): The status and future of stock quality testing. NewForest 13: 491-514. https://doi.org/10.1023/A:1006571718255

Popović, V., Ćirković-Mitrović, T., Lučić, A., Rakonjac, Lj., Ratknić, M. (2015): Odnos morfoloških pokazatelja kvaliteta jednogodišnjih sadnica gorskog javora (Acer pseudoplatanus L). Šumarstvo 4: 67-74.

Popović, V., Rakonjac, Lj., Lučić, A. (2017): Pokazatelji kvaliteta dvogodišnjih sadnica gorskog javora (Acer pseudoplatanus L.). Šumarstvo 1-2. Udruženje šumarskih inženjera i tehničara Srbije. p. 43-52.

Ratknic, M., Rakonjac, Lj. (2010): Sessile oak and hornbeam forest resources in Peshter plateau. Sustainable Forestry, 61-62, Institute of Forestry, p. 27-39.

Roller, K. J. (1977): Suggested minimum standards for containerised seedlings in Nova Scotia. Department of Fisheries and Environment Canada, Canadian Forestry Service, Information Report M-X-69 (1-18).

Saha, S., Kuehne, C., Kohnle, U., Brang, P., Ehring, A., Geisel, J., Leder, B., Muth, M., Petersen, R., Peter, J., Ruhm, W. (2012): Growth and quality of young oaks (Quercus robur and Quercus petraea) grown in cluster plantings in central Europe: a weighted metaanalysis. Forest Ecology and Management. 283:106-18.

SRPS D.Z2.112, 1968. Forest seedlings - Broadleaved species.

StatSoft Inc., 2004. STATISTICA, version 7.

Tsakaldimi, M., Ganatsas, P., Jacobs, D.F. (2012): Prediction of planted seedling survival of five Mediterranean species based on initial seedling morphology. NewForest 44:327339. https://doi.org/10.1007/s11056-012-9339-3

Wilson, B. C., \& Jacobs, D. F. (2006): Quality assessment of temperate zone deciduous hardwood seedlings. New Forests, 31(3): 417-433.

\section{ANALYSIS OF MORPHOLOGICAL QUALITY PARAMETERS OF ONE-YEAR OLD BARE ROOT SESSILE OAK (Quercus petraea (Matt.) Liebl) SEEDLINGS}

Vladan POPOVIĆ, Aleksandar LUČIĆ, Ljubinko RAKONJAC, Ivona KERKEZ JANKOVIĆ

\section{Summary}

Sessile oak is one of the two most common species of oak in nursery production of Serbia. According to the Serbian Law on Forest Reproductive Material, seedlings of hardwood species produced must meet the quality criteria according to the current standard SRPS D.Z2.112:1968 ("Official Gazette RS", no. 135/2004, 8/2005). The quality of the seedlings is largely an indicator of the success of afforestation (Wilson and Jacobs, 2006). This study aims to determine which of the morphological parameters of one-year-old sessile oak seedlings are the most indicative to measure the most accurate quality assessment with minimal time and expenses.

For the conducted research seedlings were produced in the nursery of the Institute of Forestry in Belgrade, in uniform environmental conditions from seed collected in seed 
stand RS-2-2-qpe-22-169. The following morphological parameters were measured: root collar diameter, the height of seedlings, seedlings mass above and below ground in dry condition and root volume. Based on the measured values, ratios were calculated height:root collar diameter, mass above ground:mass of underground part of seedling and quality index. The sturdiness quotient was calculated by Roller 1977 and the quality index by Dickson et al. 1960. Root volume was measured by the water extrusion method (Burdett, 1979).

The measured data were statistically processed in Statistica 7 software package (StatSoft, Inc. 2004). For the measured morphological parameters, mean, standard deviation, minimum and maximum values were calculated. The interdependence of the measured parameters was determined by calculating a linear correlation coefficient, and the influence of the position of seedlings in the seedbed on morphological parameters was examined using one-way analysis of variance.

Measured one-year old sessile oak seedlings according to the measurement data obtained are within the range of values prescribed by the standard for hardwood seedlings. Although the most commonly used quality indicators are seedling height and root diameter, the quality index has proven to be the most comprehensive morphological indicator of seedling quality. The strongest correlation was found between the root collar diameter and the quality index $(0.74)$. The quality index is in a strong, positive correlation with all measured parameters, except for the sturdiness quotient. A one-way analysis of variance results indicate the absence of position influence on seedlings observed parameters.

Based on all the data analyzed, the height of the seedlings and the root collar diameter justify their wide application in the evaluation of seedling quality. This is supported by the strong positive correlation of these two parameters with the quality index, which is the most comprehensive morphological indicator of seedlings quality.

\title{
АНАЛИЗА МОРФОЛОШКИХ ПАРАМЕТАРА КВАЛИТЕТА ЈЕДНОГОДИШЫИХ САДНИЦА КИТЫАКА (Quercus petraea (Matt.) Liebl) СА ГОЛИМ КОРЕНОМ
}

\author{
Vladan POPOVIĆ, Aleksandar LUČIĆ, Ljubinko RAKONJAC, Ivona KERKEZ JANKOVIĆ
}

\section{Резиме}

Храст китњак једна је од две најчешће врсте храста у расадничкој производњи Србије. Према Закону о шумском репродуктивном материјалу Републике Србије (“S1. glasnik RS”, nо. 135/2004, 8/2005), саднице лишћарских врста морају да испуњавају критеријуме квалитета према важећем стандарду SRPS D.Z2.112:1968. Квалитет садница у великој мери је показатељ успешности пошумљавања (Wilson and Jacobs, 2006). Циљ овог истраживања је да се утврде који од морфолошких параметара једногодишњих садница китњака су најиндикативнији за најтачнију процену квалитета уз минимално трошење времена и средстава.

За спроведена истраживања саднице су произведене у расаднику Института за шумарство у Београду, у уједначеним условима средине од семена сакупљеног у семенској састојини RS-2-2-qре-22-169. Мерени су следећи морфолошки параметри: пречник у кореновом врату, висина садница, маса надземног и подземног дела садница у сувом стању и запремина корена. На основу измерених вредности израчунати су односи висина:пречник у кореновом врату, маса надземног:маса подземног дела саднице и индекс квалитета. Коефицијент једрине израчунат је по Roller 1977, а индекс квалитета по Dickson et al. 1960. Запремина корена је измерена методом истискивања воде (Burdett, 1979). 
Мерени подаци су статистички обрађени у програмском пакету Statistica 7 (StatSoft, Inc. 2004). За истраживане морфолошке параметре израчунати су средња вредност, стандардна девијација, минималме и максималне вредности. Међузависност истраживаних параметара утврђена је рачунањем линеарног коефицијента корелације, а утицај положаја садница у леји на морфолошке параметре испитан је применом једнофакторијале анализе варијансе (One-Way ANOWA).

Мерене једногодишње саднице храста китњака према добијеним подацима мерења налазе се у опсегу вредности које су прописане стандардом за саднице тврдих лишћара. Иако су најчешће коришћени показатељи квалитета висина саднице и пречник кореновог врата, индекс квалитета се показао као најобухватнији морфолошки показатељ квалитета садница. Најјача корелација пронађена је између пречника кореновог врата и индекса квалитета $(0,74)$. Индекс квалитета је у снажној, позитивној корелацији са свим измереним параметрима, осим са коефицијентом једрине. Једнофакторијална анализа варијансе указује на одсуство утицаја положаја садница на истраживане параметре.

На основу свих анализираних података, висине садница и пречник кореновог врата оправдавају своју широку примену у процени квалитета садница. У прилог томе иде и јака позитивна повезаност ова два параметра са индексом квалитета, који прдставља најобухватнији параметар кавлитета. 